\title{
HUBUNGAN PEMBERIAN SUSU FORMULA DENGAN KEJADIAN DIARE PADA BAYI USIA 0-6 BULAN
}

\author{
Nuriza Astari, Aryu Candra $\mathbf{K}^{*}$ \\ Program Studi Ilmu Gizi Fakultas Kedokteran Universitas Diponegoro \\ Jl.Dr.Sutomo No.18, Semarang, Telp (024) 8453708, Email : gizifk@ undip.ac.id
}

\begin{abstract}
Background: Diarrhea is a condition of abnormal or unusual stool, where the volume is increase, have soft or watery consistensty and more frequent (more 3 times / day in neonates and more than 4 times / day). The incidence of diarrhea and mortality are still high, especially in infants who received formula milk. Formula feeding with a bottle that is not according to the procedure increases the risk of diarrhea due to bacteria and oral moniliasis increased, as a result of the provision of water and poor sterilization. Objective: The aim of this study is analyze association between formula feeding with the incidence of diarrhea in infants aged 0-6 months.

Methods: This is case-control study with matching on aged of the baby. The amount of subject are 80 that were selected by purposive sampling. Case group was 40 subjects with diarrhea while controls were 40 subjects who did not have diarrhea. Data was analyzed using Chi Square test statistic.

Results: The results showed $92.5 \%$ of infants in the case group suffered from diarrhea and formula-fed. All subject obtain right formula.The Bivariate analysis show, there are association formula feeding with diarrhea $(p=0.000$; $O R=14.1 ; C I=2.9$ to 66.4), there are significant association between formula feeding procedure with diarrhea ( $p$ =0.040; OR 4.1 CI = 1.21 - 8.84).

Conclusion: There are significant association between formula feeding and giving formula procedure in infants aged 0-6 months.
\end{abstract}

Keywords: infants 0-6 months; diarrhea; formula milk; case-control study

\begin{abstract}
ABSTRAK
Latar Belakang : Diare adalah suatu keadaan pengeluaran tinja yang tidak normal atau tidak seperti biasanya, dimana terjadi peningkatan volume, konsistensi lunak atau encer dan frekuensi lebih dari 3kali/hari dan pada neonates lebih dari 4 kali/hari. Angka kejadian dan kematian diare masih tinggi terutama pada bayi yang mendapat susu formula. Pemberian susu formula dengan botol yang tidak sesuai prosedur meningkatkan risiko diare karena kuman dan moniliasis mulut yang meningkat, sebagai akibat dari pengadaan air dan sterilisasi yang kurang baik.

Tujuan : Mengetahui hubungan pemberian susu formula dengan kejadian diare pada bayi usia 0-6 bulan. Metode : Jenis Penelitian adalah analitik observasional dengan rancangan kasus kontrol dengan matching berdasarkan usia bayi. Pengambilan subjek secara purposive sampling. Kelompok kasus adalah 40 subjek yang mengalami diare sedangkan kontrol adalah 40 subjek yang tidak mengalami diare. Data dianalisis menggunakan uji statistic Chi Square.

Hasil : Hasil penelitian menunjukkan sebesar 92,5\% bayi pada kelompok kasus menderita diare dan diberi susu formula. Semua subjek mendapatkan jenis susu formula yang tepat. Analisis bivariat menunjukkan pemberian susu formula berhubungan dengan kejadian diare $(p=0.000 ; O R=14,1 ; C I=2,9-66,4)$, cara pemberian susu formula berhubungan dengan kejadian diare ( $p=0.040 ;$ OR 4.1; $C I=1.21-8.84)$.
\end{abstract}

Simpulan : Terdapat hubungan bermakna antara pemberian susu formula dengan kejadian diare pada bayi usia 06 bulan dan cara pemberian susu formula dengan kejadian diare pada bayi usia 0-6 bulan.

Kata kunci : bayi 0-6 bulan; diare; susu formula; studi kasus kontrol

\section{PENDAHULUAN}

Diare masih menjadi masalah kesehatan dunia terutama di negara berkembang. Diare sering terjadi pada anak-anak dan balita, frekuensi serta angka kematiannya tinggi. Di Indonesia, diare merupakan salah satu masalah utama kesehatan. Pada tahun 2003 angka kematian akibat diare pada anak-anak dan balita di bawah 5 tahun mencapai 1,87 juta. Delapan dari 10 kematian ini terjadi dalam dua tahun pertama kehidupan. Rata-rata, anak-anak usia di bawah 3 tahun pada negara berkembang mengalami tiga episode diare setiap tahun. ${ }^{1,2,3}$ Berdasarkan data yang disajikan SDKI 2012 dari 16.380 anak yang disurvei sebanyak $14 \%$ balita mengalami penyakit diare. Data dari profil kesehatan di Indonesia pada tahun 20002010 terlihat kenaikan insiden diare. Pada tahun 2000 IR (Insidence Rate) penyakit diare 301 per 1000 penduduk tahun 2006 naik menjadi 423 per 1000 penduduk dan tahun 2010 menjadi 411 per 1000 penduduk. $^{4}$

Diare adalah suatu keadaan pengeluaran 
tinja yang tidak normal atau tidak seperti biasanya. Perubahan yang terjadi berupa peningkatan volume, keenceran dan frekuensi, dengan atau tanpa lendir darah lebih dari $3 \mathrm{kali} / \mathrm{hari}$ dan pada neonates lebih dari 4 kali/hari. ${ }^{5,6}$ Diare termasuk penyakit berbahaya karena dapat mengakibatkan kematian dan dapat menimbulkan KLB (Kejadian Luar Biasa). Penyebab utama kematian karena diare adalah dehidrasi. Angka kejadian dan kematian diare pada anak-anak di negara berkembang masih tinggi terutama pada anak yang mendapat susu formula. Pemberian susu formula dengan botol yang tidak sesuai prosedur meningkatkan risiko diare karena kuman dan moniliasis mulut yang meningkat, sebagai akibat dari pengadaan air dan sterilisasi yang kurang baik. ${ }^{7}$ Untuk bayi yang diberi ASI eksklusif angka kejadian diare lebih sedikit hal ini dikarenakan ASI mengandung antibodi yang tidak dimiliki oleh susu formula. Selain itu ASI juga memiliki zat kekebalan dalam pencernaan. Pada waktu lahir sampai beberapa bulan sesudahnya, bayi belum dapat membentuk kekebalan sendiri secara sempurna oleh sebab itu diperlukan ASI sebagai asupan utama bayi. Bayi sering tidak mendapatkan ASI eksklusif, berbagai macam faktor menyebabkan sang ibu tidak dapat memberikan ASI nya, seperti ASI tidak keluar, ASI keluar sedikit, Ibu bekerja dan lain sebagainya. Oleh sebab itu susu formula dimaksudkan untuk menggantikan fungsi ASI. Orang tua berperan besar dalam menentukan penyebab anak terkena diare. Bayi dan balita yang masih memperoleh ASI eksklusif umumnya jarang terkena diare karena tidak terjadi kontaminasi dari luar. Disamping itu jika bayi yang minum ASI menderita diare, dan pemberian ASI tetap diteruskan dalam penatalaksanaan diare maka diare akan lebih cepat berhenti. Hal ini disebabkan adanya komponenkomponen anti infeksi pada ASI. ${ }^{5}$ Penggunaan susu formula bayi yang tidak benar atau tidak tepat dapat menimbulkan bahaya kesehatan,terutama diare. Susu formula merupakan media yang baik bagi pertumbuhan bakteri, sehingga kontaminasi mudah terjadi terutama jika persiapan dan pemberian kurang memperhatikan segi antiseptik. ${ }^{8}$

Menurut data profil kesehatan Semarang tahun 2011 puskesmas Mangkang merupakan salah satu wilayah kerja yang prevalensi kejadian diare pada bayi tinggi. Data tersebut menunjukkan Incidence Rate melebihi target (IR 21/1000 penduduk). Peningkatan kejadian diare terjadi pada bayi setiap tahunnya, hal ini terjadi karena dimungkinkan pemberian susu formula yang tidak tepat yang disebabkan oleh beberapa faktor. Oleh karena itu peneliti tertarik untuk meneliti hubungan pemberian susu formula dengan kejadian diare pada bayi usia 0-6 bulan.

\section{METODA}

Penelitian ini termasuk dalam lingkup penelitian gizi masyarakat yang dilakukan pada bayi usia 0-6 bulan di wilayah kerja puskesmas Mangkang Semarang pada bulan Juni 2013. Penelitian menggunakan rancangan case control dengan matching berdasarkan usia bayi. Pengambilan subjek dilakukan dengan cara purposive sampling sebanyak 80 subjek (40 subjek kelompok kasus dan 40 subjek kelompok kontrol) yaitu dengan memilih responden yang dapat memberikan informasi yang cukup dalam menjawab pertanyaan penelitian. ${ }^{9} \quad$ Untuk pengambilan sampel pada kelompok kontrol (tidak diare) dalam penelitian menggunakan Simple Random Sampling (SRS). Kelompok kontrol adalah ibu-ibu yang mempunyai bayi usia 0-6 bulan yang tidak mengalami diare dan tercatat di wilayah kerja Puskesmas Mangkang. Sampel kelompok kontrol diambil secara acak dimana masing-masing subjek memiliki peluang yang sama dan independen untuk terpilih menjadi sampel. ${ }^{10}$ Variabel bebas (independen) dalam penelitian ini adalah pemberian susu formula kepada bayi usia 0-6 bulan, pemberian susu formula termasuk jenis susu formula dan cara pemberian susu formula pada bayi usia 0-6 bulan. Cara pemberian susu formula adalah cara penyiapan dan pemberian yang sesuai dengan petunjuk dalam kemasan susu formula. Jenis pemberian susu formula adalah ketepatan jenis susu formula yang diberikan. Tahap pertama yang dilakukan ketika pengambilan data adalah penandatanganan lembar persetujuan sebagai responden untuk mengisi kuesioner. Kuesioner yang sudah dibagikan diisi oleh responden. Kuesioner yang telah diisi lalu dianalisis secara statistik, meliputi analisis univariat dan bivariat Analisis univariat digunakan untuk mendeskripsikan masing-masing variabel. Analisis bivariat digunakan untuk melihat hubungan variabel independen dengan variabel dependen dengan menggunakan Chi Square, dan untuk mengetahui besar risiko variabel independen terhadap variabel dependen diekspresikan sebagai OR (Odd Ratio). 
HASIL PENELITIAN

Karakteristik Responden

Hasil penelitian menunjukkan dari 80 responden yang telah mengisi kuesioner usia ratarata responden adalah 20-25 tahun untuk kelompok kasus (55\%) dan kontrol (70\%), Karakteristik responden berdasarkan pendidikan sebagian besar tamat SMA untuk kelompok kasus dan kontrol. Rata - rata responden bekerja sebagai buruh untuk kelompok kasus dan kontrol. (Tabel 2)

Tabel 2. Distribusi Karakteristik Responden

\begin{tabular}{lcc}
\hline \multirow{2}{*}{ Karakteristik Responden } & Kasus & Kontrol \\
\cline { 2 - 3 } & $\begin{array}{c}\text { Diare } \\
\mathbf{n}(\%)\end{array}$ & $\begin{array}{c}\text { Tidak diare } \\
\mathbf{n}(\%)\end{array}$ \\
\hline Usia ibu (tahun) & & \\
$<20$ & $1(2.5 \%)$ & $1(2,5 \%)$ \\
$20-25$ & $22(55 \%)$ & $28(70 \%)$ \\
$26-30$ & $15(37,5 \%)$ & $9(22,5 \%)$ \\
$>30$ & $2(5 \%)$ & $2(5 \%)$ \\
Pendidikan & & \\
Tidak tamat SD & $1(2,5 \%)$ & $0(0 \%)$ \\
Tamat SD & $8(20 \%)$ & $8(20 \%)$ \\
Tamat SMP & $13(32,5 \%)$ & $12(30 \%)$ \\
Tamat SMA & $16(40 \%)$ & $18(45 \%)$ \\
Perguruan Tinggi & $2(5 \%)$ & $2(5 \%)$ \\
Pekerjaan & & $10(25 \%)$ \\
Ibu rumah tangga & $9(22,5 \%)$ & $3(7,5 \%)$ \\
Petani & $4(10 \%)$ & $15(37,5 \%)$ \\
Buruh & $19(47,5 \%)$ & $11(27,5 \%)$ \\
Pedagang & $6(15 \%)$ & $1(2,5 \%)$ \\
PNS & $2(5 \%)$ & 40 \\
\hline Total & 40 & \\
\hline
\end{tabular}

\section{Karakteristik Subjek}

Hasil penelitian menunjukkan bahwa 80 subjek penelitian, sebagian besar subjek berjenis kelamin laki-laki pada kelompok kasus $(52,5 \%)$ dan pada kelompok kontrol (60\%). Usia subjek berkisar antara 1-6 bulan dengan rerata usia 4,32 bulan. (Tabel 3)

Tabel 3. Distribusi karakteristik subjek

\begin{tabular}{lcc}
\hline Karakteristik Subjek & Kasus & Kontrol \\
\cline { 2 - 3 } & $\begin{array}{c}\text { Diare } \\
\mathbf{n}(\%)\end{array}$ & $\begin{array}{c}\text { Tidak diare } \\
\mathbf{n}(\%)\end{array}$ \\
\hline Usia bayi (bulan) & $6(15 \%)$ & $6(15 \%)$ \\
$0-3$ & $34(85 \%)$ & $34(85 \%)$ \\
$4-6$ & $21(52,5 \%)$ & $24(60 \%)$ \\
\hline Jenis Kelamin & $19(47,5 \%)$ & $16(40 \%)$ \\
Laki-laki & 40 & 40 \\
Perempuan & & \\
\hline Total & &
\end{tabular}


Tabel 4. Distribusi subjek menurut pemberian susu formula, jenis susu formula, dan cara pemberian susu formula

\begin{tabular}{|c|c|c|c|c|c|}
\hline \multirow[b]{2}{*}{$\begin{array}{l}\text { Pemberian } \\
\text { Susu Formula }\end{array}$} & Kasus & Kontrol & p value & OR & $95 \% C I$ \\
\hline & $\begin{array}{l}\text { Diare } \\
\text { n }(\%)\end{array}$ & $\begin{array}{c}\text { Tidak } \\
\text { diare } \\
\text { n }(\%)\end{array}$ & & & \\
\hline$-\mathrm{Ya}$ & $37(92,5 \%)$ & $23(57,5 \%)$ & 0,000 & 14,114 & $2,969-66,428$ \\
\hline - Tidak & $3(7,5 \%)$ & $17(42,5 \%)$ & & & \\
\hline \multicolumn{6}{|l|}{ Jenis Susu } \\
\hline \multicolumn{6}{|l|}{ Formula } \\
\hline - Tidak tepat & 0 & 0 & & & \\
\hline - Tepat & $37(92,5 \%)$ & $23(57,5 \%)$ & & & \\
\hline - ASI & $3(7,5 \%)$ & $17(42,5 \%)$ & & & \\
\hline \multicolumn{6}{|l|}{$\begin{array}{l}\text { Cara pemberian } \\
\text { susu formula }\end{array}$} \\
\hline $\begin{array}{l}\text { - Tidak sesuai } \\
\text { kemasan }\end{array}$ & $30(75 \%)$ & $13(32,5 \%)$ & 0,040 & 4,143 & $1,211-8,844$ \\
\hline $\begin{array}{l}\text { - Sesuai } \\
\text { kemasan }\end{array}$ & $7(17,5 \%)$ & $10(25 \%)$ & & & \\
\hline - ASI & $3(7,5 \%)$ & $17(42,5 \%)$ & & & \\
\hline Total & 40 & 40 & & & \\
\hline
\end{tabular}

Hampir seluruh subjek diberi susu formula pada kelompok kasus dan kelompok kontrol. Untuk Jenis susu formula, baik kelompok kasus dan kontrol diberi jenis susu formula yang tepat yaitu susu formula awal. Cara pemberian susu formula pada kelompok kasus sebagian besar tidak sesuai petunjuk pada kemasan susu formula.

Hubungan pemberian susu formula, jenis susu formula dan cara pemberian susu formula dengan kejadian diare

Secara statistik terdapat hubungan bermakna antara pemberian susu formula dengan kejadian diare $(p$ value $=0,000$ OR 14,114 CI = 2,969 - 66,428). Hasil analisis untuk jenis susu formula menunjukkan tidak ada hubungan dengan kejadian diare pada bayi usia 0-6 bulan. Berdasarkan hasil statistik terdapat hubungan bermakna antara cara penyajian susu formula dengan kejadian diare $(p$ value $=0,040$ OR 4,143 dan CI $=1,211-8,844)$.

\section{PEMBAHASAN}

Pada kelompok kasus 92,5\% diberikan susu formula. Pada kelompok kontrol 57,5\%. Jika dirata-rata pemberian susu formula pada kedua kelompok mencapai $75 \%$. Dengan demikian dapat disimpulkan pemberian ASI eksklusif hanya 25\%. Tingginya pemberian susu formula pada bayi disebabkan karena lebih mudah dan cepat sehingga apabila ASI ibu tidak keluar atau ASI keluar sedikit susu formula dapat mengantikan fungsi
ASI. Begitu pula dengan ibu yang bekerja, susu formula merupakan pilihan yang mereka anggap paling baik untuk menggantikan fungsi ASI.

Pemberian susu formula bertujuan untuk mengganti asupan ASI sebagai asupan utama bagi bayi usia 0-6 bulan. Hasil analisis bivariat pada hubungan pemberian susu formula dengan kejadian diare pada bayi usia $0-6$ bulan menunjukkan hubungan yang bermakna $(\mathrm{p}=0,000$ OR $14,1 \mathrm{CI}=2,9-66,4)$. Pemberian susu formula pada bayi usia 0-6 bulan mempunyai hubungan dengan kejadian diare, dan bayi yang diberikan susu formula mempunyai risiko 14,1 kali terpapar diare, dibandingkan dengan bayi yang tidak diberi susu formula. Berdasarkan hasil analisis pada penelitian ini, menunjukkan bahwa responden yang memberikan susu formula kepada bayi nya berisiko bayinya terkena diare. Terjadinya diare pada bayi yang diberi susu formula karena bayi dengan usia dibawah 6 bulan sistem pencernaannya belum sempurna, dan umur bayi berperan terhadap berkurangnya frekuensi defekasi, dimana hal ini merupakan petunjuk dari semakin matangnya kapasitas "water-conserving"

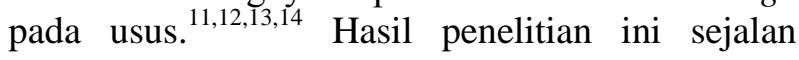
dengan penelitian yang dilakukan oleh Fitriya (2010) yang menunjukkan bahwa ada hubungan pemberian susu formula dengan kejadian diare pada bayi 0 - 6 bulan, dimana $p$ value $=0,001 .^{15}$ 
Hasil analisis bivariat hubungan jenis pemberian susu formula dengan kejadian diare pada bayi usia 0-6 bulan tidak menujukkan hubungan yang bermakna, karena semua responden memberikan jenis susu formula awal untuk bayi usia 0-6 bulan. Karakteristik responden sebagian besar adalah tamat SMA dimana responden memiliki pengetahuan yang cukup untuk memilih jenis susu formula yang tepat. Penelitian ini sama dengan penelitian yang dilakukan oleh Aniqoh (2006) di Puskesmas Sekardangan Kabupaten Sidoarjo, yang menyatakan bahwa tidak ada hubungan antara jenis susu formula dengan kejadian diare pada bayi. ${ }^{16}$

Hasil analisis dari cara pemberian susu formula memiliki hubungan bermakna dengan kejadian diare pada bayi usia 0-6 bulan yaitu $\mathrm{p}=$ 0,040 OR 4,14 CI=1,211-8,844. Bayi yang diberi susu formula dengan cara yang tidak tepat atau tidak sesuai kemasan mempunyai risiko terkena diare sebesar 4,14 dibanding dengan yang diberi susu formula secara tepat. Berdasarkan hasil wawancara pada penelitian ini, masih banyak ibuibu yang memberikan susu formula dengan cara yang tidak tepat yaitu tidak sesuai petunjuk kemasan. Selain itu sebagian besar responden tidak mencuci tangan sebelum menyiapkan susu formula hal ini terjadi karena terkadang ibu lupa dan memang tidak terbiasa untuk cuci tangan terlebih dahulu, botol yang dipakai tidak disteril karena responden tidak memiliki alat untuk mensteril botol susu bayi, dan adapun yang mensteril botol susu hanya dengan direbus tanpa mengetahui berapa suhu yang tepat untuk mensteril botol susu tersebut. Hal ini juga sesuai dengan penelitian yang dilakukan Aniqoh (2006) di Puskesmas Sekardangan Kabupaten Sidoarjo, yang menyatakan bahwa ada hubungan cara pemberian dengan kejadian diare pada bayi $(\mathrm{p}=0,01) .{ }^{16}$ Pernyataan Dinkes RI (2005) menyatakan bahwa salah satu perilaku masyarakat yang dapat menyebabkan penyebaran kuman penyebab diare dan meningkatnya risiko terjangkit diare yaitu menggunakan botol susu yang memudahkan pencemaran kuman penyebab diare. ${ }^{17}$

\section{KETERBATASAN PENELITIAN}

Dalam penelitian ini keterbatasan penelitian meliputi adanya diagnosis diare pada bayi yang hanya berdasarkan hasil wawancara responden, hal ini dapat menimbulkan bias karena diare seharusnya ditentukan dengan diagnosis yang lebih tepat yaitu dengan catatan medis dokter, Jenis diare juga tidak diketahui secara pasti, dimana dapat berpotensi bias karena dimungkinkan diare terjadi karena infeksi lain atau tertular dari orang lain. Cara penyajian susu formula hanya berdasarkan petunjuk dari kemasan yang beragam, ada yang lengkap tetapi ada juga beberapa yang kurang lengkap atau kurang jelas.

\section{SIMPULAN}

Pada penelitian ini didapatkan subjek sebesar 92,5\% pada kelompok kasus dan 57,5\% pada kelompok kontrol menderita diare dan diberi susu formula. Hasil statistik diketahui terdapat hubungan antara pemberian susu formula dengan kejadian diare pada bayi usia 0-6 bulan. Distribusi berdasarkan jenis pemberian susu formula secara keseluruhan responden sudah memberikan jenis susu formula yang tepat. Untuk cara penyajian susu formula pada bayi terdapat hubungan yang bermakna pada cara penyajian susu formula dengan kejadian diare pada bayi usia 0-6 bulan sehingga meningkatkan rIsiko diare pada bayi.

\section{SARAN}

Diharapkan bagi penelitian selanjutnya dapat meneruskan penelitian yang sama dengan menghubungkan variabel yang berbeda guna mempertahankan dan meningkatkan kesehatan bayi sejak dini. Untuk para ibu agar dapat membaca dan mengikuti petunjuk yang ada di kemasan susu serta lebih meningkatkan kebersihan dan higienitas dalam menyiapkan susu formula. Untuk para produsen susu formula diharapkan mencantumkan petunjuk pemakaian secara lebih lengkap dan jelas sehingga dapat mencegah kejadian diare karena cara pemberian susu formula yang tidak tepat.

\section{DAFTAR PUSTAKA}

1. Bhan M, Mahalanabis D, Pierce N, Rollins N, Sack D, Santosham M. The Treatment of Diarrhoea A manual for Physicians and other Senior Health Workers.2005. Dari:http://whqlibdoc.who.int

2. Department of Child and Adolescent Health and Development (CAH). Handbook IMCI Integrated Management of Childhood Illness. 2005. Dari: http://whqlibdoc.who.int

3. Wijaya Yulianto. Faktor Risiko Kejadian Diare Balita Di Sekitar TPS Banaran Kampus Unnes. 2012.

4. Survei Demografi dan Kesehatan Indonesia.Jakarta, Indonesia: Badan Pusat Statistika, 2012[cited 2013 Apr 10]:23.

5. Hidayat A. Pengantar Ilmu Kesehatan Anak untuk Pendidikan Kebidanan. Surabaya:Salemba Medika, 2008. 
6. Sofwan R, Diare Pada Anak. PT. Bhuana Ilmu Populer Kelompok Gramedia. Jakarta: Paramadita L; 2010. hal. 1-2.

7. Suraatmaja S, Suwendra P, Hamid A, Santosa H, Soetjiningsih, Kari I, Karkata K, Hamzah E, Ayu I, Asmi S. Di dalam: Soetjiningsih, editor. ASI petunjuk untuk tenaga kesehatan seri gizi klinik., Jakarta: EGC hal. 18-19.

8. Puspitaningrum, Citra, Yuni, Rusana. Perbedaan Frekuensi Diare antara Bayi yang diberi Asi Eksklusif dengan Bayi yang diberi Susu Formula di Wilayah Kerja Puskesmas Gandrungmangu I Kabupaten Cilacap, 2006. Dari:http://litbangstikes.wordpress.com

9. Sudigdo S, Sofyan I. Dasar-dasar metodologi penelitian klinis edisi ke 2.Jakarta: Sagung Seto; 2002.

10. Murti. Desain dan Ukuran Sampel untuk Penelitian Kuantitatif dan kualitatif Bidang di Kesehatan.Yogyakarta: Gajah Mada University Press. 2006.

11. Muñoz-Quezada S, Bermudez M, Chenoll E, Genovés S, Gomez C, Diaz J, Matencio E, Bernal MJ, Romero F, Ramón D, Gil A. Competitive inhibition of three novel bacteria isolated from faeces of breast milk-fed infants against selected enteropathogens. Department of Biochemistry and Molecular Biology II, Institute of Nutrition and Food Technology José Mataix, Biomedical Research Centre, University of Granada. Januari: 2013. http://www.ncbi.nlm.nih.gov

12. Sudigbia I. Gambaran Perubahan Mukosa Usus Pada Diare Anak. Makalah pada pertemuan ilmiah IDI Magelang. 2004,

13. Soeparto P, Sumbangan dan Peran Kaum Profesional Dalam Mendukung Program Penyakit Saluran Cerna di Era Otonomi. Dalam: Kongres Nasional II BKGAI. Bandung: BKGAI, 2003: 17 27.

14. Davidson GP. Viral Causes of Acute Diarrhea During Infancy and Childhood. Dalam: Lebenthal E. Textbook of Gastroenterology and Nutrition in Infancy. 2 nd ed. New York: Raven Press. 11071116.

15. Irawati F. Hubungan Pemberian Susu Formula dengan Pertahanan Tubuh terhadap Kejadian Diare pada Bayi Usia 0-6 Bulan di Desa Punggung Kecamatan Punggung Mojokerto. Unimus. 2013

16. Aniqoh Machwijatul. 2006, Hubungan Antara Pemberian Susu Formula Dengan Kejadian Diare pada Bayi Umur 0- 12 Bulan (Studi di Puskesmas Sekardangan Kabupaten Sidoarjo). Dari:fkm@unair.ac.id [13 Mei 2009].

17. Depkes RI. 2005, Status Lingkungan Hidup Indonesia 2005. Dari: www.menlh.go.id[30 Juli 2009] 